\title{
INDONESIA'S ECONOMIC STABILIZATION AND REHABILITATION PROGRAM: AN EVALUATION
}

\author{
Hong Lan Oei*
}

Indonesia's Stabilization and Rehabilitation Program

Economic Change in Indonesia

Since October 1966, Indonesia has witnessed rapid and farreaching economic changes which followed the similarly drastic and fundamental changes on the political scene in the year following the abortive political coup d'etat of 1 0ctober 1965. While the results of such rapid economic changes are not discernible yet on the surface, it is anticipated that the institutional and other changes which have taken and are taking place will gradualiy reshape the entire economic future of Indonesia.

One fundamental change which has occurred is the transition from an officially pronounced guided economy to one in which market forces are given relatively free reign to determine the allocation of resources, still, of course, within the framework of government control and indirect guidance. 1

These changes are evident from the far-reaching decontrol and debureaucratization measures introduced in the past eight months which have gradually restored the effectiveness of fiscal and monetary control in the economy. Of greater importance is the less obvious transition from economic chaos and absence of policy during the previous regime to rational economic principles which involves a change in attitude and behavior on the part of those responsible for economic policy. This has been manifested in the formation of an Economic Stabilization Council headed by

* The author is a member of the United Nations ECAFE Secretariat in Bangkok. However, the views and opinions expressed in the paper, which was prepared by him in his personal capacity, are not necessarily those of ECAFE. The author is greatly indebted for helpful comments and information by members of the Council on Economic and Political Advisers to President Suharto and by the numerous government officials in the Central Bank, Central Bureau of Statistics, the National Planning Agency, the Ministry of Finance and by the teaching staff of the University of Indonesia.

1. The term liberalization has an unsavory connotation in Indonesia and is generally avoided. 
the Acting President and comprising three subcouncils in the monetary, distribution and production fields. This council in its day to day operations is assisted by a braintrust consisting of university professors to advise it on economic and political matters.

For the layman, the most noticeable result of these changes has been the apparent success of the Government, especially in the first half of 1967, in its efforts to curb the inflation which, in 1965 and in the first part of 1966, assumed runaway proportions. This was accompanied by a comparatively successful stabilization of the rupiah exchange rate. These achievements were of course not easy. When the inflation rate was brought down from about 141 per cent in the first quarter of 1966 to about 35 per cent in the similar period of 1967 , and further to 0.65 per cent in April 1967 and even to a slight decline of prices by 0.21 per cent in May $1967,{ }^{2}$ there were understandably considerable signs of tension and dissatisfaction on the part of many. Inflation, which had almost become an institution during 1961-1966, has benefited those who were able to gear their activities to it. These included speculative traders, companies which supplied construction and other materials to the huge projects of those days, companies which received cheap credits at far below market rates and cheap foreign exchange allocations, etc. It also includes, however, people who could supplement their incomes by small scale buying and selling of second hand goods, activities which have become unprofitable with the success of the stabilization program and have gradually disappeared. Stabilization measures were also hurting government departments and ministries who were used to supplementary budgets far exceeding their original budgets but who are at present instructed to adhere to the original budget of 1967.

On the theoretical side, critics of the Government argue that in Indonesia, where the two prime movers of the economy are the public sector and the export sector, curbing of these vital sectors through a balanced budget and tight credit policy may bring about a recession and even a decline in the national income. Some critics argue further that the present stabilization policies, if carried to the extreme, will not create the conditions for subsequent rapid economic growth, especially if little or no attention is paid to rehabilization of infrastructure and the communications system, the ports and other physical prerequisites for rapid economic development.

In spite of these criticisms, the Government is determined to continue its program of stabilization and to emphasize the attack on inflation. Runaway inflation, which had virtually become institutionalized in Indonesia, must be eliminated entirely not only in its monetary manifestations but more importantly

2. Price index for Djakarta based on 62 commodities. Biro Pusat Statistik (Central Bureau of Statistics). 
in its physical and psychological effects in the form of institutions and attitudes geared to inflation. At the same time, the Government has deemed it necessary to permit some relaxation especially in its tight money policy, particularly after March 1967 .

The Accelerating Pace of Inflation

Table 1 shows the increase in the consumer price index for the period 1961-1967.

$$
\begin{aligned}
& \text { Table 1. Consumer Price Index for Djakarta, 1961- } \\
& 1967 \\
& (\text { March 1957-February } 1958=100)
\end{aligned}
$$

\begin{tabular}{lrc}
\hline End of the Period & Index & $\begin{array}{c}\text { Percentage Rise } \\
\text { During Periods }\end{array}$ \\
\hline 1961 & 380 & 65 \\
1962 & 976 & 157 \\
1963 & 3,226 & 128 \\
1964 & 5,234 & 135 \\
1965 & 36,347 & 594 \\
1966 & 267,276 & 635 \\
1967 & & 35 \\
1st quarter & 361,640 & 3.6 \\
\hline
\end{tabular}

Source: Biro Pusat Statistik.

It shows that the rate of inflation was increasing at an accelerating pace. If allowed to continue, it might have brought about economic and even political collapse, as was the case in China in 1949. In that country, the price index for Shanghai, already 7,000 times the 1937 base by the end of 1946, increased fifteenfold during the following year and another 29 times by the end of July 1948. Introduction of the gold yuan currency after that was of no particular consequence as the price index rose again from 186.3 in August to 3,583.7 at the end of the year after which the currency completely broke down when the index rose to $20,957,009$ in April $1949 .^{3}$

3. N. K. Chiang, The Inflationary Spiral: The Experience in China 1939-1950 (New York: John Wiley, 1958). 
Although Indonesia's inflation in 1965 and 1966 still assumed far smaller proportions than in the China of $1949,{ }^{4}$ an acceleration of the inflation rate was imminent if no measures were taken to counter it. This is because inflation "feeds" itself through psychological and other factors which accentuate the effects on prices of increasing money supply. This is clearly demonstrated in Table 2, which shows the relation between money supply and the price index. As inflation became worse in 1965 and the first quarter of 1966, the rise in the price level in every quarter exceeded the increase in the money supply. Thus the elasticity of price with respect to money supply, which is determined by psychological and other factors, became very large, or 5.38 in the first quarter of 1965. The effects of the 3 October 1966 stabilization measures are clearly evident on the table. Both monetary expansion and prices increased at a lower rate during the last quarter of 1966 and the first quarter of 1967.

The importance of qualitative factors in both China and Indonesia is evident from the fact that in both cases stabilization measures were taken by a new government which came into power at a time of hyperinflation. It is even more apparent in the case of Germany in 1923 when no such change in power occurred. The monetary reform introduced in Germany in October 1923 to check the much more advanced stage of inflation than that in Indonesia could not wait for the creation of the conditions for a monetary recovery, i.e., the solution of the reparations question and the improvement of the economic and political situation. Even Luther, the minister responsible for the decree, described it as the work of one "who builds a house, beginning with a roof." 5 The success of the monetary reform came quite unexpectedly and was accompanied by a rapid re-establishment of the equilibrium of the national budget and by an appreciable improvement in living conditions. The "miracle of the rentenmark" became a common expression.

Actually, the "miracle of the rentenmark" was to a great extent the result of psychological factors. The stability of the rentenmark was not due to the possibility of converting the latter into mortgage securities which yielded a 5 per cent interest in gold, well below the market rate of interest. The difference between printing the word rentenmark on a piece of paper instead of the equivalent bizlion marks is purely psychological. At that time lack of confidence in the legal paper mark was such that "any piece of paper, however problematical its guarantee, on which was written 'constant value' was accepted more

4. It was roughly comparable to inflation in China in 1945-1946.

5. Constantino Bresciani Turroni, The Economics of Inflation (New York: Barnes and Noble, 193I), p. 335 . 


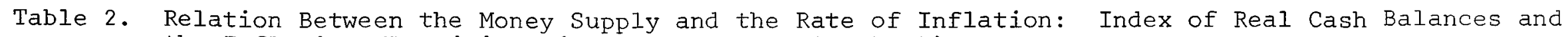
the Inflation Elasticity (Quarterly Data 1963-1967)

\begin{tabular}{|c|c|c|c|c|c|c|c|c|c|}
\hline \multirow[b]{2}{*}{ End } & \multirow[b]{2}{*}{ of Period } & \multirow{3}{*}{$\begin{array}{l}\text { Cost of } \\
\text { Living } \\
\text { Index } \\
\text { Base } \\
\text { March } \\
1963=100\end{array}$} & \multicolumn{3}{|c|}{ Money Supply } & \multirow{2}{*}{\multicolumn{2}{|c|}{$\begin{array}{l}\text { Quarterly Per- } \\
\text { centage Increase }\end{array}$}} & \multirow{3}{*}{$\begin{array}{l}\text { Index of } \\
\text { Real Cash } \\
\text { Balance } \\
\text { Base: } \\
\text { March } \\
1963=100^{a}\end{array}$} & \multirow{3}{*}{$\begin{array}{c}\text { Inflation } \\
\text { Elasticity } \\
\text { With Respect } \\
\text { to Money } \\
\text { Supply }\end{array}$} \\
\hline & & & \multirow[b]{2}{*}{$\begin{array}{c}\text { (In millions } \\
\text { of new } \\
\text { rupiahs) }\end{array}$} & \multirow{2}{*}{$\begin{array}{l}\text { Of which: } \\
\text { Demand } \\
\text { Deposits } \\
\text { (in per- } \\
\text { centages) }\end{array}$} & \multirow{2}{*}{$\begin{array}{l}\text { Index of } \\
\text { Money } \\
\text { Supply } \\
\text { Base } \\
\text { March } \\
1963=100 \\
\end{array}$} & & & & \\
\hline Year & $\begin{array}{c}\text { Quarter } \\
\text { and } \\
\text { Month } \\
\end{array}$ & & & & & $\begin{array}{l}\text { Centage } \\
\text { Cost of } \\
\text { Living }\end{array}$ & $\begin{array}{l}\text { Money } \\
\text { Monease } \\
\text { Supply }\end{array}$ & & \\
\hline 1963 & lst & 100 & 144.0 & 25 & 100 & -- & -- & 100 & -- \\
\hline & 2 nd & 113 & 170.1 & 25 & 124 & 13 & 24 & 110 & 0.54 \\
\hline & $3 r d$ & 131 & 221.3 & 30 & 154 & 16 & 24 & 118 & 0.67 \\
\hline & 4 th & 166 & 263.4 & 33 & 183 & 27 & 19 & 110 & 1.92 \\
\hline 1964 & lst & 243 & 293.4 & 32 & 204 & 46 & 12 & 84 & 3.83 \\
\hline & 2 nd & 202 & 367.0 & 30 & 255 & -17 & 25 & 126 & -0.68 \\
\hline & $3 r d$ & 295 & 467.5 & 31 & 323 & 46 & 27 & 109 & 1.70 \\
\hline & $4 t h$ & 389 & 675.1 & 33 & 531 & 32 & 64 & 137 & 0.50 \\
\hline 1965 & lst & 554 & 823.0 & 24 & 572 & 43 & 8 & 103 & 5.38 \\
\hline & 2 nd & 632 & $1,116.9$ & 27 & 776 & 14 & 36 & 123 & 0.39 \\
\hline & $3 r d$ & 1,069 & $1,627.7$ & 27 & 1,130 & 69 & 46 & 106 & 1.50 \\
\hline & 4 th & 2,704 & $2,582.0$ & 24 & 1,793 & 153 & 59 & 66 & 2.59 \\
\hline 1965 & Ist & 6,526 & $5,688.8$ & 23 & 3,951 & 141 & 120 & 61 & 1.18 \\
\hline & 2 nd & 10,260 & $10,268.0$ & 19 & 7,131 & 57 & 81 & 70 & 0.70 \\
\hline & $3 r d$ & 14,927 & $14,473.1$ & 17 & 10,051 & 45 & 41 & 87 & 1.10 \\
\hline & 4 th & 19,887 & $21,024.4$ & 25 & 14,600 & 33 & 45 & 73 & 0.73 \\
\hline 1967 & lst & 26,908 & $26,086.3$ & 25 & 18,116 & 35 & 24 & 67 & 1.46 \\
\hline & 2nd & 27,877 & $32,066.3$ & 25 & 22,266 & 3.6 & 23 & 80 & 0.16 \\
\hline
\end{tabular}

Sources: Cost of living index: Biro Pusat Statistik. Original base 1957-1958=100. Money Supply: B. N. I. Unit I (Central Bank).

Notes: a. Index of Money Supply divided by Cost of Living Index.

b. Percentage increase in Cost of Living divided by Percentage increase in Money Supply. 
willingly than the paper mark." 6 In fact, while the money supply rose significantly in real terms, there was a continuous fall in the value of paper marks in circulation. The real shortage of paper money led to a rapid rise in the velocity of circulation and to the apparently paradoxical result that it became easier to redeem paper money; few notes would have been presented for conversion to gold had the opportunity been given.

The same situation was apparent in Indonesia, as shown in Table 2. While the money supply continued to rise at an accelerating pace, real cash balances fell and the shortage of money was reflected in a general increase in interest rates. In fact, the money supply in May 1967 was in real terms only 75 per cent of that in March 1963. It must be noted that the German stabilization of the exchange was not obtained by means of contraction, nor even by stopping the expansion of the circulation of legal currency. On the contrary, the quantity of legal currency rose considerably. ${ }^{7}$ This phenomenon is not difficult to explain. The increased confidence in the paper money led to a decline in the velocity of circulation as consumers, producers and merchants ceased to be preoccupied with the necessity to reduce their cash balances to the minimum. In the stabilization measures taken by the Government in Indonesia, it may be as important to impress upon the people the seriousness of the intention to balance the budget as it is actually to reduce the deficit and to restrict monetary expansion.

The Basis and Tools of Government Policy

The role of non-economic factors in the present program is apparent from the foregoing and the fundamental changes in the Indonesian economy could probably not have been accomplished without changes in the political climate. The present Government was formed immediately after the June-July 1966 session of the People's Consultative Assembly which has again become Indonesia's highest legislative body after a period of incapacity during the last years of the previous regime. During that session, it was decreed that "the problem of improving the people's economy must be given first priority amongst other national affairs, whilst the method of dealing with it needs to be based upon rational and realistic economic principles." 8 The

6. Ibid., p. 347 .

7. Ibid., P. 337 .

8. "Decree No. XXIII concerning Renewal of Policy as to the Basis of the Economy, Finance and Development," Decision of the Fourth Plenary Session of the Madjelis Permusjawaratan Rakjat Sementara 20th June to 5 th July 1966 (Djakarta: Ministry of Information), pp. 68, 71 and 72 (English edition). 
decree further stated that, in the short term, stabilization and rehabilitation should take precedence over development and that the scale of priorities in the short term program should be: stabilization, i.e., checking inflation, and rehabilitation, by which is meant:

1. adequately supplying the need for foodstuffs;

2. rehabilitation of the economic infrastructure;

3. increasing export activities;

4. adequately supplying the need for clothing.

With the help of the International Monetary Fund, a stabilization program was drawn up on the basis of the above decision, which had as its twin objectives: the curbing of the inflation leading to a relatively stable price level in conformity with people's purchasing power and the adequate financing, (in both rupiah and foreign exchange) of the rehabilitation program. ${ }^{9}$

The implementation of the above program was accomplished through a series of actions starting with the "3 October 1966" measures with far-reaching consequences for exchange stabilization domestic credits and the government budget. This was followed by supplementary measures promulgated on the loth of February and the 28 th of July 1967 which were meant to eliminate price distortions which had developed over the years owing to government inefficiency and inflation.

Since the Indonesian inflation has been diagnosed as a demand pull inflation, stabilization measures are directed primarily to curbing demand. They consist of policies in four major areas:

1. The government budget. As the bulk of government current expenditures consists of wages which could hardly be reduced, the realization of a balanced budget can only be achieved through a drastic increase in government revenues.

2. The balance of payments. A major overhaul of the foreign exchange system (to be discussed in detail below), coupled with rescheduling of foreign debts and new loans, will provide most of the expected increases in government revenue. The measures also included simplified regulations for exports and imports decontrol.

3. Tight money policy. The 3 October measures also included a restriction on government credit and a substantial rise in interest rates.

9. Pokok 2 Kebidjaksanaan Stabilisasi dan Rehabilitasi Ekonomi Kabinet Ampera (mimeographed), p. 5. 
4. Decontrol of prices. Introduced in October and followed up in February 1967, the measures were intended to eliminate price distortions through substantial increases in tariffs of public utility rates and transportation charges. In order to evaluate the government's program, these four groups of policy measures will be discussed in detail in the following part.

\section{Detailed Evaluation of the Program}

\section{The Central Government Budget}

The chronic deficit in the government budget since 1951 has been widely identified as one of the most important forces generating the acceleration in the rate of inflation. Its effect on the money supply is obvious as such deficits were mainly financed by the creation of new money. While the excess of government expenditure over revenue contributed to the increase in monetary demand, it exercised also the psychological effect of decreasing people's confidence in the currency.

Table 3 shows that the deficit as a percentage of revenue continuously rose from 16.7 per cent in 1960 to 617.8 per cent in the first quarter of 1966 after which it declined. Expressed in 1960 prices, however, both expenditures and revenues showed a consistently declining trend until the first quarter of 1966 . This decline was more pronounced when the budget is expressed as percentage of national income and more severe in the case of revenues than expenditures. Thus while deficit financing under moderate inflationary conditions may increase the government's claim on resources, under hyperinflation the real claim on resources declined. This occurred in spite of the enunciated policies of socialism and increased government participation in the economy. Under conditions of hyperinflation, large fortunes were amassed in the private sector and the deteriorating government apparatus increasingly failed to adjust revenues to the changing conditions. The importance of a balanced budget was also recognized by the previous regime during its last days of power when the Government in December 1965 hastily prepared a budget of sorts which aimed at a balance through drastically raising the prices charged by public enterprises, gasoline and transportation in particular. It envisaged among other things, a 100-fold increase in the revenues from petroleum products. It was this budget, with the accompanying increases in prices, which precipitated political unrest and student demonstrations leading to the downfall of the regime.10

10. Opposition to the new rate increases was voiced initially in an economic seminar organized by the students of the University of Indonesia, which featured prominent economists from that University as the main speakers. See KAMI, Fakultas Ekonomi, University of Indonesia, The Leader, the Man and the Gun. Proceedings of the Economic seminar held in Djakarta, January 1966 . 
Table 3. The Central Government Budget in Relation to National Inomce, 1960-1967 (Millions of new Rupiahs)

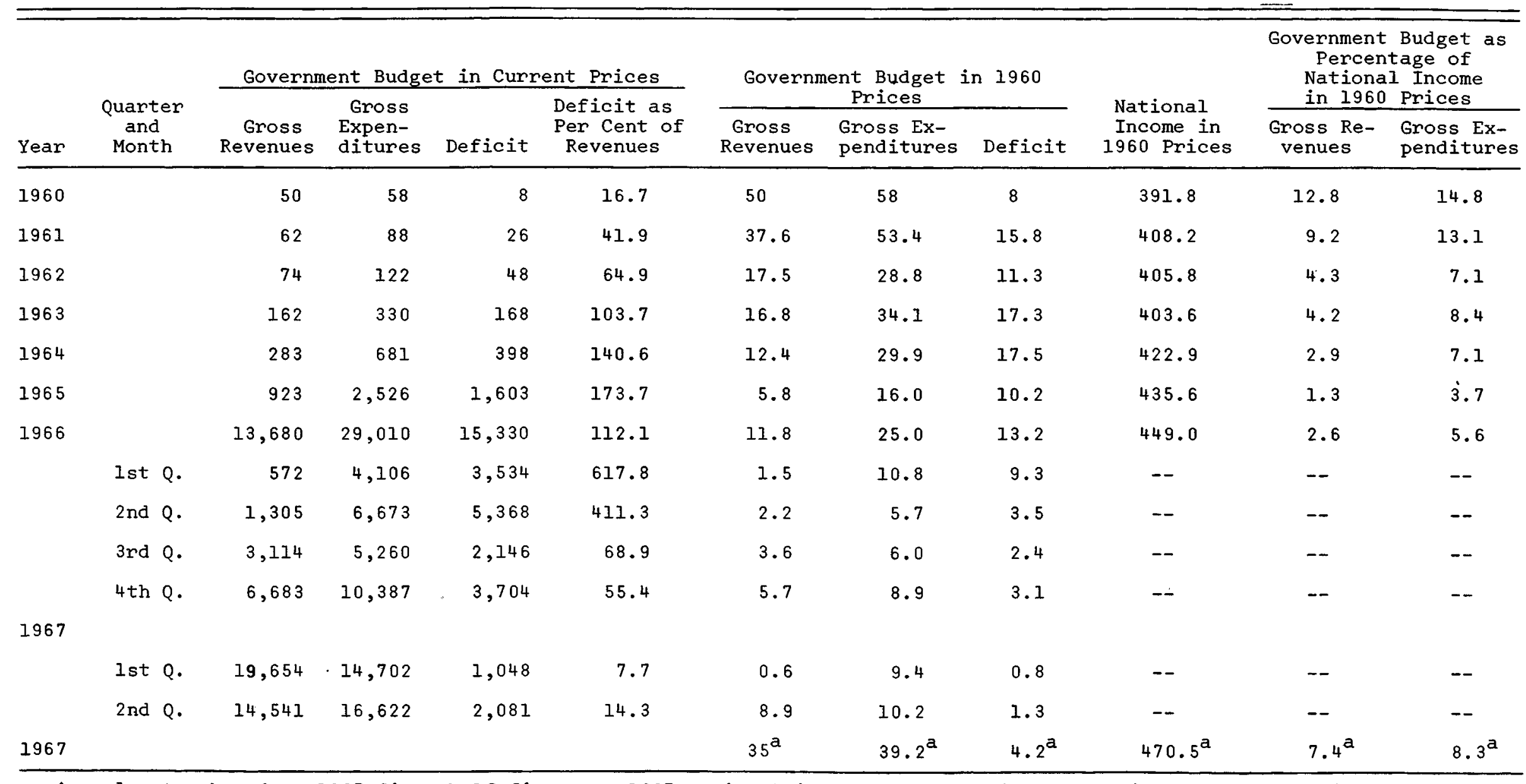

a. Annual rates based on 1967 first half figures. 1967 national income figure estimated by Biro Pusat Statistik.

Source: Biro Pusat Statistik. 
The present Government is committed to a balanced budget policy by decisions of the People's Congress of $1966^{11}$ and on 24 December 1966, the parliament approved the 1967 budget which shows total receipts and expenditures to be balanced at $\operatorname{Rp} 81.3$ billion. Thus total receipts in 1967 will be almost six times and total expenditures nearly three times those of 1966. As percentages of national income, both expenditures and revenues show significant gains (see Table 3 ). This budget, however, contains two items which virtually cancel each other: repayment of foreign credits and rescheduling of repayment, in the amount of Rp 9 billion (the rupiah equivalent of U.S. \$90 million at the assumed exchange rate of $\mathrm{Rp} 100$ to U.S. \$l used in the budget).

At the meetings with foreign creditors in Paris and Amsterdam agreement was reached to reschedule this loan repayment. Tables 4 and 5 show the revised budget balanced at the reduced level of $\mathrm{Rp} 72.3$ billion rupiahs. As the table shows, the 1967 budget anticipates increases in all items of revenues and expenditures over 1966, a consequence of the continued high rate of inflation in 1966. The 1967 budget, however, differs from its predecessors in more than one fundamental sense, making it a more effective instrument of control.

The first major change from previous budgets is related to the complete overhaul of the foreign exchange system (See below). As shown in Table 4, two major sources of revenue in 1967, i.e., profits from Bonus Exports (BE) exchange funds and rupiah proceeds from foreign credit $B E$ sales, were nonexistent in 1966. Government foreign exchange funds, obtained through the surrender by exporters of part of their foreign exchange proceeds and through foreign credits, were not sold in 1966 but were allocated to the various government departments and holders of import licenses at low exchange rates. Now the proceeds from foreign credits and from exports are sold on the foreign exchange market created for that purpose. Thus the system of foreign exchange allocations to government departments has been abolished.

The resultant flexibility in revenues will automatically provide increases as the $B E$ rate of exchange rises. Thus, a major portion of government revenues is isolated from the inflationary forces. The new system shows a weakness in that revenues are to a large extent determined by proceeds from the foreign sectors, i.e., trade and credits. Even though Indonesia managed to obtain the full $\$ 200$ million credits anticipated in the budget for 1967, which should bring in at least $\mathrm{Rp} 20$ billion in $B E$ revenues, realization of such credits is expected to be not larger than $\$ 150$ million, producing not more than Rp 15

11. See Decisions of the Fourth Plenary Session..., article 47, P. 79. 
billion in revenue to the Government. Moreover, if the 1967 export target of $\$ 475$ for 1967 is not achieved, government revenues will fall below the $R p 14.23$ billion target in the budget. 12

Table 4. Government Receipts, 1966-1968 (in billions of new rupiahs)

\begin{tabular}{|c|c|c|}
\hline & $\begin{array}{c}1966 \\
\text { Actuals }\end{array}$ & $\begin{array}{c}1967 \\
\text { Budget }\end{array}$ \\
\hline Direct taxes & 2.41 & 8.47 \\
\hline $\begin{array}{l}\text { Income taxes } \\
\text { Corporate taxes } \\
\text { Other }\end{array}$ & $\begin{array}{l}0.62 \\
0.66 \\
1.14\end{array}$ & $\begin{array}{l}1.50 \\
6.95 \\
0.02\end{array}$ \\
\hline Indirect taxes & 8.44 & 39.33 \\
\hline $\begin{array}{l}\text { Sales and turnover taxes } \\
\text { Excises } \\
\text { Import duties } \\
\text { Profits from B E exchange funds } \\
\text { Exchange taxes } \\
\text { Others }\end{array}$ & $\begin{array}{l}1.65 \\
2.30 \\
1.34 \\
-- \\
0.98 \\
2.17\end{array}$ & $\begin{array}{r}7.00 \\
8.29 \\
9.06 \\
14.23 \\
-- \\
0.75\end{array}$ \\
\hline Non tax revenues & 2.82 & 24.50 \\
\hline $\begin{array}{l}\text { Excess profit levies (including oil companies) } \\
\text { Share of profits from state enterprises } \\
\text { Rupiah proceeds from foreign credits B.E. sales } \\
\text { Miscellaneous }\end{array}$ & $\begin{array}{l}0.22 \\
0.01 \\
-- \\
2.60 \\
\end{array}$ & $\begin{array}{r}\mathrm{p} \cdot \mathrm{m} \\
0.30 \\
20.50 \mathrm{a} \\
3.70 \\
\end{array}$ \\
\hline Total & 13.7 & $72.3^{a}$ \\
\hline
\end{tabular}

a. The original budget called for a balanced budget at a level of Rp 81.3 billion. As a result of debt rescheduling talks, Rp 9 billion debt repayment which was to be financed by a loan should be stricken from the budget.

Source: Department of Finance.

An overreliance on foreign trade revenues in the form of duties and taxes is not unique in Indonesia. In fact, many, if not all, developing countries have to rely more heavily on

12. For further details, see section on Foreign Trade and Payments below. The $\mathrm{BE}$ exchange rate is a fluctuating rate, but for budget purposes, an exchange rate of $\mathrm{Rp} 100$ to the U.S. dollar is assumed throughout. 
indirect sources than on direct taxes. However, even by developing countries' standards, Indonesia's revenues from taxes appear extremely low. This seems to be one of the consequences of hyperinflation. The grand total of all tax revenues, from domestic economic activities for 1967 (direct taxes, sales and turnover taxes and excises) amounts to only Rp 23.76 billion or about 3.2 per cent of the projected 1967 national income level. 13 If taxes on domestic activities should be increased to about 10 per cent of national income the result would be a current figure of Rp 71.3 billion, enough to finance the entire budget.

Table 5. Central Government Expenditures, 1966-1967 (in billions of new rupiahs)

\begin{tabular}{|c|c|c|}
\hline & $\begin{array}{c}1966 \\
\text { Actual }\end{array}$ & $\begin{array}{c}1967 \\
\text { Budget }\end{array}$ \\
\hline Domestic expenditures & 22.20 & 56.96 \\
\hline Routine budget & 20.06 & 44.50 \\
\hline $\begin{array}{l}\text { Personnel expenditures } \\
\text { (Rice allowances) } \\
\text { (Other) } \\
\text { Material expenditures } \\
\text { Subsidies }\end{array}$ & $\begin{array}{l}12.71 \\
(6.19) \\
(6.52) \\
2.78 \\
2.40\end{array}$ & $\begin{array}{l}25.26 \\
(10.37) \\
(14.89) \\
8.92 \\
6.40\end{array}$ \\
\hline Internal debt servicing & 0.09 & 0.62 \\
\hline Development budget & 2.13 & 12.46 \\
\hline External expenditures & 6.81 & 24.34 \\
\hline $\begin{array}{l}\text { Foreign debt repayment } \\
\text { Rice imports } \\
\text { other government imports and services } \\
\quad \text { (including military) }\end{array}$ & $\begin{array}{l}0.40 \\
1.37 \\
5.04\end{array}$ & $\begin{array}{c}3.43^{\mathrm{a}} \\
-- \\
11.91\end{array}$ \\
\hline Total & 29.0 & $72 \cdot 3^{a}$ \\
\hline
\end{tabular}

a. The original budget called for a balanced budget at a level of Rp 81.3 billion. As a result of debt rescheduling talks, Rp 9 billion debt repayment which was to be financed by a loan should be stricken from the budget.

Admittedly, an intensification of tax collection needs a great deal of reform and a thorough reorganization of the tax

13. Using the price index for March 1967, the $R_{p} 23.76$ billion can be deflated to 1960 prices of Rp 15.12 million, or about 3.2 per cent of the projected 1967 national income of Rp 470 million, also at $1960^{\circ}$ prices. 
collection machinery. Assuming an average household size of five and the present Indonesian population figure of 110 million, the number of households is 22 million. At present data from the tax directorate show a total of only 260,000 registered taxpayers of which only 30,000 actually pay income tax. This is an exceptionally low figure even for a developing country. The majority of Indonesians, it should be added, pay taxes and levies in the form of illegal or semi-legal "contributions" which can be quite substantial, especially outside the capital. While such levies have increased with the rate of inflation, especially in the past year, they do not contribute to government revenues. It may be noted that, for the approximately 22 million households, the Directorate of Taxes employs only around 12,000 people of whom 8,000 are in the field.

The second important measure which characterizes the 1967 budget is the decree by the Government not to permit supplementary budgets. This is an important decision, for in years past, Indonesian budgets were mere exercises on paper which were never adhered to. From 1961 to 1965, this situation became steadily worse and in 1965 actual expenditures were 2 1/2 times those budgeted while revenues were only about 40 per cent higher than budgeted. Because of the still large deficit in the last quarter of 1966 quarterly ceilings for fiscal operations were introduced in January 1967 and an attempt was made to balance the budget on a quarterly basis. For the first quarter of 1967, the expenditure level was set at only 10 per cent of total budget for the year, due to the seasonal character of revenue.

Meanwhile, the figures released for the first half of 1967 show total expenditures of $\mathrm{Rp} 3 \perp .3$ billion and revenues of $R_{p} 28.2$ billion, indicating a deficit of $R_{p} 3.1$ billion. 14 This has prompted the Presidlum to issue a new instruction urging ministries to adhere strictly to the buaget and not to request new and supplementary budgets. 15

Uther important differences between the 1967 budget and previous ones include the abolition of all special budgets. In previous years, such budgets were created for special purposes of the President and no account was made to the general public about their execution. Indeed, the officially published budget deficits were greatly underestimated by the amount of these special budgets. The consolidation of all central government budgets into a single budget and the restoration of budget control to the Ministry of Finance are further measures to increase

14. Government of Indonesia, Report to the Parliament on implementation of the Stabilization and Rehabilitation Program, 10 July 1967.

15. Instruksi Presidium Kabinet Ampera No. 26/U/In/5/1967. 
the effectiveness of fiscal policy. These major changes have significantly retarded the inflationary rate as shown in Tables 1 and 2. However, the strict enforcement of budgetary ceilings has seriously affected government departments, which also have suffered a loss of revenue from the restricted size of the development budget in 1967, partly because the Government has decided not to start new projects. In the past many expenditures classified as development expenditures by the ministries were actually current expenditures which were in fact used to supplement the low wages of civil servants. These included various imaginary research projects and surveys which were never carried out or inadequately carried out, and the establishment of committees and various projects to bolster the ministerial budget. Thus, while most criticisms have been directed against the various "show" projects of the past President, the real extent of waste of government funds for "development" is much larger, as wasteful projects under the guise of, e.g., "research into potential riches of Indonesia's seas and natural wealth" existed in all departments. This type of "development expenditure" has been severely curtailed in the present budget.

The large budget allocation for personnel expenditures and rice allowances reflects the overgrown bureaucracy inherited by the present Government. According to Department of the Budget figures, the total number of people on the Central Government payroll is 1.94 million, including 1.68 active employees and 260,000 pensioners. 16 During the first part of 1967 , heads of government departments and state enterprises were instructed by the Cabinet Presidium to ascertain the number of excess employees and to arrange for their transfer to other jobs within the Government or, alternatively, make an effort to find employment for them in the private sector. During the transition period, such people would be placed on inactive status with pay during six months to two years. Re-employed pensioners, employees 55 years of age and over, and chronic absentees, however, are discharged without benefit of inactive status, but with severance pay for aged employees and chronic absentees. Employees discharged for superannuation will receive full salary for six months plus any long service leave payments to which they are entitled; chronic absentees will be paid for three months plus long service payments.

The above arrangements appear more benevolent than they are in reality. Because of the inflation, salaries have been reduced considerably in real terms and most people are forced to accept

16. 522,000 were in the armed forces and 166,000 were civilians employed by the armed forces. Of the remaining, 406,000 were employed by the Central Government and the rest by regional authorities. 
employment with three or more companies. Simultaneously, chronic absenteeism was, especially during the last regime, the norm rather than the exception. In spite of the waves of salary increases, the latest in April 1967, in which allowances and salaries were increased by 50 per cent and rice allowances from 8 to 10 kilos monthly, salaries are still far below minimum requirements of employees.

Indeed, the initial successes of stabilization paradoxically caused more hardship for these fixed income groups in the short run. Under inflationary conditions, they were able to supplement their incomes easily through speculative trading on the side, through selling on the market of rice and other rations, through corruption and through the various imaginary "research and development" projects in their departments referred to above. Now, while their salaries have been raised and have become a little more meaningful through relatively more stable prices, these additional sources of income have virtually disappared. This brought about a number of unwanted consequences such as the increase in petty corruption and illegal "taxes," an upsurge in the wave of criminality especially in the larger cities, and an increase in smuggling which has now become semilegal in several regions, as regional authorities who feel the pinch of the tight budget policy think that they should themselves "create" their own sources of revenue, causing danger to the national export target and government revenues from exports.

\section{Foreign Trade and the Balance of Payments}

Reforms in the field of foreign trade and payments constitute the second cluster of policies designed to stabilize the economy. The continuing and accelerating rate of inflation has undoubtedly had its adverse repercussions on the foreign trade and payments of Indonesia which in turn influenced the rate of inflation. While the excessive exchange restrictions encouraged capital flight, providing an added impetus to currency depreciation as a result of inflation and insecurity, nearly stagnant and even declining exports, coupled with stringent import control and restriction have in their turn again influenced the rate of inflation by disrupting the domestic flow of goods. These factors combined have caused a depreciation of the rupiah exchange rate exceeding the rate of inflation which in turn has induced more capital flight.

Since 1961, Indonesia's balance of payments has been in continuing deficit. The over-all payments deficit amounted to \$161 million in 1961 , decreased to $\$ 88$ million in 1964 and rose again sharply to $\$ 235$ million in 1965 when official loans and grants inflow declined sharply, as Table 6 shows, necessitating financing of the payments deficit through deferred payments and other short-term liabilities and by a rundown in foreign assets. 
Table 6. Balance of Payments Summary 1963-1967 (in millions of U.S. dollars)

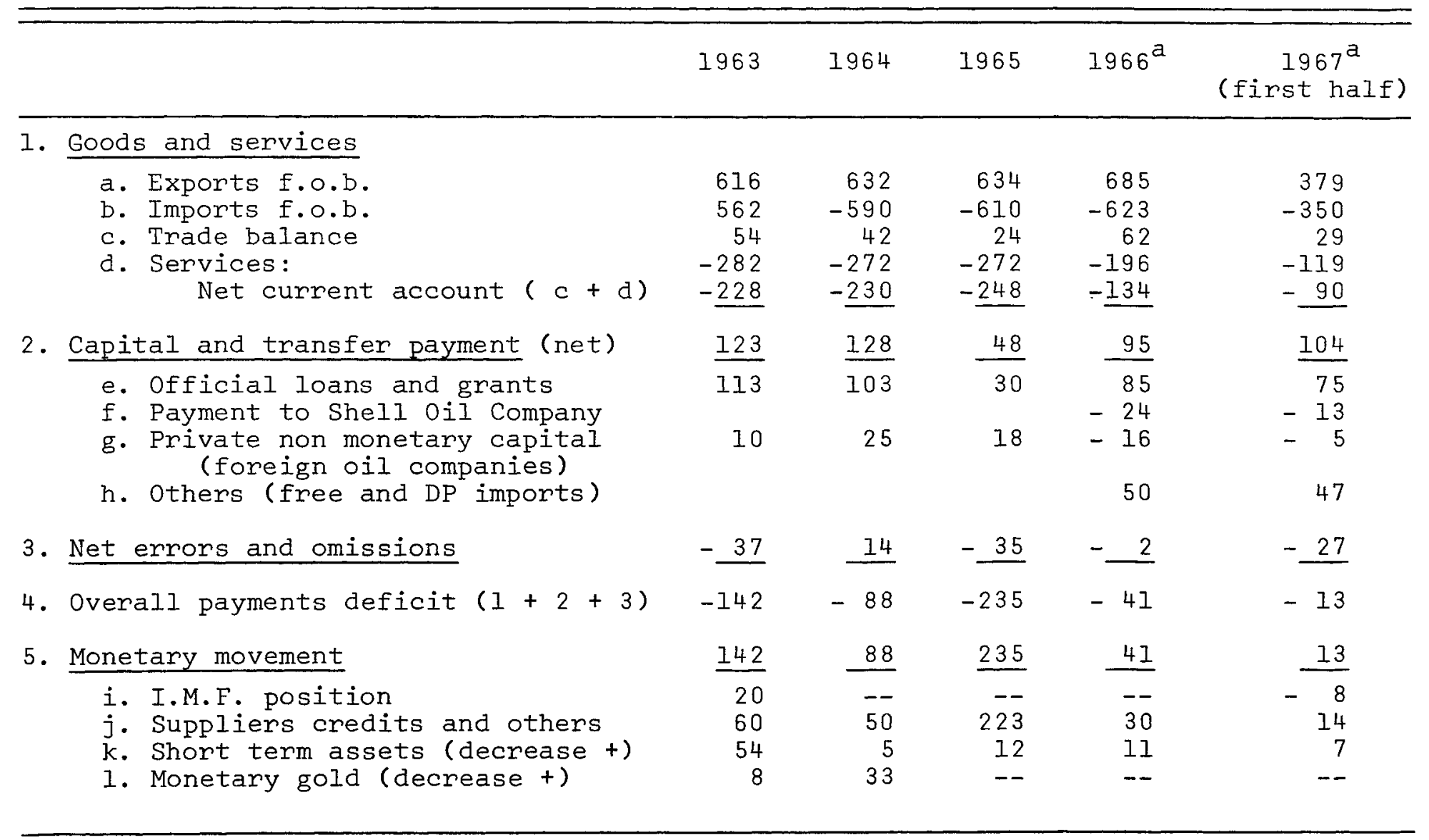

a. Provisional figures.

Source: Compiled and condensed from official government sources and I.M.F. 
For some time the Central Bank was unable to honor even cash letters of credit and had to suspend payment on foreign trade and on short-term loans. Thus, a serious payments crisis developed at the time of the abortive coup.

The 1966 provisional figures, as shown in Table 6, indicate an over-all payments deficit of $\$ 41$ million, considerably lower than the 1965 figure. The preliminary figures for the first half of 1967 show a current account deficit of $\$ 90$ million and an inflow of loans and grants of $\$ 75$ million. It is expected that the agreements concluded in Scheveningen will considerably accelerate aid utilization.

Exports, which should be one of the important prime movers of development in developing countries everywhere, have been stagnant and have declined significantly in recent years, as shown in Table 7.

The main factor preventing exports from increasing was the foreign exchange regulations whereby exporters received the major part of their earnings in rupiahs at official exchange rates which lagged far behind market rates. As the spread between the official rate and the free market rate became wider, the exporter was put increasingly at a disadvantage and unrecorded exports increased. This in all its variations meant essentially the same thing: that the exporter was being taxed excessively.

In order not to stop exports altogether, various schemes have been devised to give exporters additional incentives. On 11 February 1966, the Bonus Export (BE) system was introduced. Under this system, exporters receive a portion of their earnings in the form of foreign exchange certificates called Bonus Export or BE's which they can sell on the free market or use to import commodities on the BE list. Exports were divided into three categories, i.e., (1) strong exports such as rubber and palm oil, comprising 90 per cent of total exports; (2) Medium strong exports, such as spices, cattle fodder, comprising about 8 per cent of total exports; and ( 3 ) Weak or new exports, such as handicrafts, vegetables, etc., comprising only 2 per cent of total exports. The proportion of earnings received in the form of $B E$ varies according to the category being the highest for the third category to encourage such "weak" exports. These proportions have been increased three times since on May 1960, on 3 October 1966 and again on 28 July 1967.

Under the 3 October reforms, exporters of category 1 commodities receive 50 per cent of their earnings in $B E$ and the other 50 per cent in rupiahs at the fixed exchange rate of 10 rupiahs to one dollar. Category 2 commodities receive 75 per cent and category 3 commodities receive 90 per cent in the form of $\mathrm{BE}$. The $\mathrm{BE}$ exchange rate fluctuates according to supply and demand and was around 100 rupiahs per dollar at the time of 
Table 7. Composition of Exports, 1952-1966 (f.o.b. in millions of U.S. Dollars)

\begin{tabular}{|c|c|c|c|c|c|c|c|c|}
\hline \multirow[b]{3}{*}{ Year } & \multirow[b]{3}{*}{$\begin{array}{l}\text { Total } \\
\text { Exports }\end{array}$} & \multirow{3}{*}{$\begin{array}{l}\text { Petroleum } \\
\text { and Its } \\
\text { Products }\end{array}$} & \multirow{3}{*}{$\begin{array}{l}\text { Total } \\
\text { Other } \\
\text { Exports }\end{array}$} & \multicolumn{5}{|c|}{ of which: } \\
\hline & & & & \multicolumn{2}{|c|}{ Rubber } & \multirow[b]{2}{*}{ Tin } & \multirow[b]{2}{*}{ Copra } & \multirow[b]{2}{*}{$\begin{array}{l}\text { Palm } \\
\text { Oil }\end{array}$} \\
\hline & & & & Estates & $\begin{array}{c}\text { Small } \\
\text { Holders }\end{array}$ & & & \\
\hline 1952 & 934.3 & 191.3 & 743.0 & 200.6 & 223.3 & 86.1 & 53.1 & 26.6 \\
\hline 1953 & 840.2 & 204.6 & 635.6 & 138.9 & 133.9 & 80.6 & 57.7 & 28.6 \\
\hline 1954 & 866.5 & 227.1 & 639.4 & 104.8 & 166.4 & 59.5 & 51.4 & 26.7 \\
\hline 1955 & 945.5 & 215.8 & 729.7 & 171.8 & 259.7 & 59.5 & 35.4 & 24.2 \\
\hline 1956 & 926.2 & 255.5 & 670.9 & 154.5 & 206.2 & 62.0 & 39.2 & 27.1 \\
\hline 1957 & 954.4 & 302.8 & 651.6 & 145.9 & 203.6 & 55.5 & 40.5 & 26.0 \\
\hline 1958 & 790.7 & 315.2 & 475.5 & 108.8 & 153.2 & 35.4 & 18.2 & 23.7 \\
\hline 1959 & 931.0 & 285.7 & 645.3 & 143.4 & 275.9 & 36.1 & 27.6 & 19.2 \\
\hline 1960 & 840.8 & 220.8 & 620.0 & 134.0 & 243.2 & 50.6 & 29.1 & 20.0 \\
\hline 1961 & 788.2 & 260.9 & 527.3 & 122.5 & 184.6 & 33.3 & 34.7 & 21.4 \\
\hline 1962 & 663.7 & 215.8 & 447.9 & 101.6 & 196.9 & 34.9 & 14.8 & 17.8 \\
\hline 1963 & 695.6 & 268.7 & 426.9 & 95.2 & 147.4 & 18.9 & 13.6 & 20.0 \\
\hline 1964 & 724.2 & 267.4 & 456.8 & 98.5 & 135.2 & 31.6 & 23.5 & 26.9 \\
\hline 1965 & 707.7 & 271.9 & 435.8 & 86.5 & 135.4 & 37.9 & 18.0 & 27.5 \\
\hline 1966 & 678.7 & 203.6 & 475.1 & 90.8 & 132.1 & 30.7 & 15.1 & 33.3 \\
\hline
\end{tabular}

\section{Source: Biro Pusat Statistik.}


regulations. 17 In order to stimulate regional development, regions from which exports originated receive from the Central Government a 10 per cent foreign exchange allocation called ADO at payment of the subsidized Rp 10 per dollar. This share is taken from the government portion of foreign exchange and does not interfere with exporters' earnings. ADO exchange may be used to import goods or sold on the free market as BE's. dollar:

An exporter of category I therefore receives per U. S.

50 per cent at a BE rate of 100 rupiahs per dollar -- 50 rupiahs 50 per cent at the fixed rate of 10 rupiahs per dollar-- 5 rupiahs Total per U.S. \$ 55 rupiahs

This means an effective tax of 45 per cent at the $B E$ rate of 100 rupiahs per dollar. In order to provide additional incentives to the exporters, the 3 october regulations retained the so-called checkprices for export commodities. These are prices below the world market prices on which basis the BE percentages are calculated. The premium above the checkprice, called overprice retained by the exporter abroad, may be legalized and sold as Devisa Pelengkap (supplementary foreign exchange) or DP.

Formerly, foreign exchange resulting from overprice had to be kept secretly abroad by the exporter and constituted a capital flight which was semi-legal. The legalizing of such overprice proceeds was expected to bring back part of such DP exchange, and as shown on the balance of payments table for 1966 and 1967, this has occurred. Such DP exchange was not originally recorded as export proceeds, but is included in the capital inflow account. This is in conformity with the fact that proceeds from certain invisibles are also classified as DP exchange.

Another step towards trade liberalization was taken by the Government in the first quarter of 1967. It involved the elimination of checkprices for category 3 , weak exports. Thus, exporters of this group may officially keep all their foreign exchange or sell it as DP exchange. The total exports of this group amount to a mere $\$ 10$ million or 2 per cent of total exports, but the move is significant as a test case to show how exports can be stepped up as a result of complete decontrol of the exchange system.

On the import side, the 3 October regulations included significant decontrol measures which transformed the $B E$ system from a mere export incentive arrangement to an exchange certificate market with a freely fluctuating rate. Under the new system,

17. Laporan BNI Unit I kepada Presidium Kabinet Ampera, 30 January 1967 (Central Bank Report to the Cabinet Presidium; mimeographed, unpublished), p. 21. 
imports for a wide range of essential commodities was made possible through the use of BE's while imports for most other goods can be effected by buying $D^{\prime}$ 's from exporters. At the same time, the regulations abolished the system of import allocations for government departments and privileged importers at widely varying exchange rates. Now imports by government departments have to be undertaken through the $\mathrm{BE}$ market while the government exchange fund is sold at BE rates approaching those on the free market. Thus, with a few exceptions, the 3 october measures were clearly meant to lead the way towards a unified exchange rate from the system of multiple exchange rates which had prevailed in the past. 18

As an immediate result of these measures, the $B E$ rate appreciated from 120 rupiahs to 85 rupiahs per U.S. dollar. It remained at that level until about mid-May 1967 when it started to depreciate again. In mid-August, the $B E$ rate on the free market was around 143 while the DP rate was 160. The dollar on the free market was also commanding approximately 160 rupiahs. At that time, the Government's BE rate originating from foreign credits was 131 rupiahs per dollar. The close proximity of these rates, official and free market, is unusual and has not been experienced by Indonesia for many years.

The upsurge in the $B E$ and $D P$ rates which started in May 1967 were initiated in the private exchange market and were caused among other things by a temporary shortage of BE's as imports financed by $B E^{\prime} s$ on short-term credits had to be paid for. The government $B E$ rate followed suit for different reasons. As the first quarter of the year still showed an inflation rate of around 35 per cent and the exchange rate did not depreciate accordingly, the move to depreciate the government $B E$ rate was only meant as a corrective measure as many imported goods were cheaper than similar goods on the local market in the first quarter of 1967 .

In April 1967, the basis for calculating import duties was changed from 75 rupiahs per U.S. dollar to 90 rupiahs per dollar, at the same time the requirement that 50 per cent of duties be paid in advance was ended. Payment of 75 per cent up to 90 per cent of the cost of $\mathrm{BE}$ for non-consumption goods financed by foreign credits may be postponed until after the arrival of the goods. Also, surcharges of 50 per cent to 100 per cent of

18. The most important exception continued to be the ADO foreign exchange allocation to regional authorities (see above). Also, for some time after the 3 October regulations, the Rp 10 dollar import rate continued to apply to government imports of rice while a special rate of $\mathrm{RP} 45$ per dollar was granted for the importation of textiles for the "Lebaran" festival around the end of the year. From January 1967, however, all government imports have been valued at the Central Bank's BE rate. 
current import duties were imposed on a list of approximately fifty import items which compete with local products. This should somewhat alleviate the plight of local producers.

Meanwhile, exports increased by 7.3 per cent in 1966 over 1965 while, in the first half of 1967 , exports were 18 per cent above the corresponding period in 1966.19 The encouraging export performance in the first half of the year should, however, be seen in the light of long-term export stagnation as shown in Table 7 and the fact that large-scale smuggling still persists in spite of the more favorable treatment of exporters.

Therefore, on 28 July 1967, the Government brought still further relief to exporters in the form of increased percentages of foreign exchange according to the exporters' status. Group I commodity exporters now receive 75 per cent of their proceeds in the form of BE while group 2 get 90 per cent. Group 3 has been merged into Group 2. At the same time, the practice of overprices is being severely curtailed, and imports based on DP exchange may suffer accordingly. This measure, which is meant to induce private exporters to boost exports and to eliminate smuggling, will bring a drop in government revenues. This will be offset by an increase in the basis for calculating import duties from 90 rupiahs to 130 rupiahs per dollar. On the other hand, importers were granted credit at the relatively low rate of 4 per cent monthly on balances due. Also, under the new regulations, various types of licenses have been abolished. To simplify bureaucratic procedures in shipping, the two government shipping agencies, Bipalindo and Bapeluma, dealing with allocating shipping space to exporters and interinsular traders respectively, have been abolished.

The above measures should encourage the businessman to increase exports. Financial incentives, however, are not the only obstacles to export expansion. While these measures in the administrative field have removed some of the other obstacles, there remain a host of administrative and physical obstacles which stand in the way of rapid recovery of the export volume. For one thing, the hostile attitude in the past towards foreign investment has prevented or discouraged badly needed new

19. Quarterly export figures (excluding petroleum) for 1966 and 1967 were as follows (in million U.S. dollars):

$\begin{array}{lll}\text { Quarter } & \frac{1966}{1967} & \frac{1967}{134.7} \\ \text { First } & 114.5 & 137.3 \\ \text { Second } & 116.5 & 89.5 \\ \text { Third } & 135.8 & \text { n.a. } \\ \text { Fourth } & 125.8 & \end{array}$

Source: Report of the Government to Parliament, $10 \mathrm{July}$ 1967; Business News, Djakarta, October 18, 1967. 
investments in the plantation and mining sectors. While the new foreign investment law may encourage new investments, the effects on export production will only be felt later.

The administrative obstacles consist of those imposed by the bureaucracy, including large-scale and widespread corruption, which disrupts inter-island transportation and normal flow at the ports, increasing costs to traders and producers. A typical example is the SIPAP (surat idzin pengangkutan antar pulau), a permit which must be obtained for interinsular shipment of commodities. This type of permit is bound to become a source of malpractice and therefore of increased costs. Inefficient domestic shipping lines have increased the cost of interisland shipping to exhorbitantly high levels and the Government has recently decided to allow foreign competition in this field as well as in the field of internal air transport. Another example is the excessive costs in the ports as a consequence of too much meddling by too many authorities, some of which have no connexion whatsoever with shipping or exports but demand a share of all activities passing through their "offices."

Among the physical obstacles to a quick recovery of exports, there is the incredible deterioration of the infrastructure, including bad highways, shallow ports and a grossly inadequate communications system. The Government fully realizes the problems in this field, but the present balanced budget policy does not allow for large-scale rehabilitation of the infrastructure. Nevertheless, improvements of the infrastructure have been given top priority in the small development budget, for the second quarter of 1967 earmarks 70 per cent of development expenditures to be spent on road repairs, especially on roads along which rice will be transported or so-called "rice roads," along with dredging of ports, irrigation projects and flood control. While export figures for the first half of 1967 show that the export target of $\$ 475$ million (excluding oil) set for the year may very well be exceeded, figures of stagnant exports over the years, as shown on Table 7 suggest that the target was set low to begin with and that exports should increase at a much faster rate in order to catch up with the country's needs.

As stated earlier, the 1965 over-all deficit in the balance of payments of $\$ 235$ milition as a consequence of an abrupt decline of capital inflow and transfers started a major payments crisis. Meanwhile, external debts overdue or falling due in 1966 were estimated at about $\$ 530$ million. The new Government, at a meeting with the chief western creditor nations in Tokyo in September of 1966, requested these countries to grant a moratorium on debt payments, and to reschedule maturities in arrears and those falling due in the near future. As of June 30 , 1966, debts totalled $\$ 2$, 141 million, divided as follows:

1. Medium and long term debts, including arrears and interest on arrears, totalling \$1,934 million; 
2. Short-term debts (from 181 days to 2 years), including arrears, \$180 million; and

3. Cash credits (less than 180 days), including arrears and interest, $\$ 27$ million. 20

Preliminary agreement was reached at Tokyo, and at the following meeting at Paris in December 1966, the agreement was confirmed on principles which would constitute the basis for the negotiations of bilateral agreements. These included a grace period of four years, until the end of 1970, granted on the repayment of debts, after which repayments will be made over an eight-year period.

In the meantime, Indonesia received in 1966 new grants and credits totalling $\$ 133$ million by october consisting of $\$ 15 \mathrm{mil}-$ lion commodity and other grants and $\$ 118$ million in commodity loans from nine countries. Of particular significance is the Dutch commodity grant and loan of $\$ 18$ million signed in December 1966 following the signing of an agreement for compensation of nationalized Dutch properties in which Indonesia agreed to pay $\$ 157$ million in damages over a thirty year period. From Japan came a total of $\$ 40$ miliion in loans and grants, from India $\$ 13$ million, from the United States $\$ 45$ million in PL 480 loans, from Germany $\$ 7.4$ million with the balance in the form of commodity grants, from Australia, Britain and Canada. At the end of 1966, outstanding loans in the pipeline amounted to $\$ 43 \mathrm{mil}-$ lion, which included the $\$ 13$ million from India, $\$ 4$ million from Western Germany, \$17 million from the Netherlands and $\$ 8$ milion from the United States.21

Regarding the 1967 needs to support the stabilization and rehabilitation program, a meeting was convened in Amsterdam in February 1967 attended by the same nations of the Paris meeting plus other observers. The meeting concluded that Indonesia will need about $\$ 200$ million in balance of payments support aid for 1967 and the United States indicated at the close of the meeting its preparedness to provide about one-third of total requirements, conditional upon other governments supplying the rest and upon evidence of self-help measures on Indonesia's part.

In the first months of 1967 , several new loan agreements were reached. This included a \$10 million loan from the United States as part of the above pledge on the familiar DAC (Development Assistance Corporation) terms of seven years grace period,

20. Compiled from official government sources. Major creditor nations include the Soviet Union and the seven western creditor nations which met at Tokyo. Negotiations with eastern creditor nations were held separately.

21. All figures from unpublished official sources. 
three per cent interest and repayment in 25 years; $\$ 12.5$ million from Western Germany and a Japanese loan of $\$ 50$ million to be repaid over 20 years at 5 per cent interest with a seven-year grace period. The same agreement also provides a grant of $\$ 10$ million. At the end of June 1967, another meeting was convened in Scheveningen, the Netherlands, as a follow up of the Amsterdam meeting. With the balance of 1966 outstanding loans of about $\$ 43$ million still in the pipeline, Indonesia's needs for new assistance were put at about $\$ 160$ million. This is to be met by $\$ 65$ million from the United States, Japan $\$ 60$ million, West Germany $\$ 12.5$ million, the Netherlands $\$ 10$ million and the rest to be pledged by Australia and France.

It is of interest to note that countries granting credits have supported Indonesia's desire to put these credits and grants on sale in the market under the Bonus Export scheme outlined above. Under this system, credit BE's are purchased at slightly below market rates by importers for import of goods under the $\mathrm{BE}$ list of essential commodities. Market forces are given free reign to allocate the commodities among various users, provided that export bonuses originating from credits of a partiuclar country will have to be spent in that country on raw materials and spare parts to rehabilitate industry. This has ended the allocation system of the previous regime and at the same time it provides the Government with a significant source of revenue (see section on the budget). Meanwhile, credits from the Netherlands, Japan, India, West Germany and the United States have been put on the BE market with other countries to follow. The typing of credits by donor countries, coupled with the uniform $B E$ rate applied to credits from all sources results in the fact that credit $B^{\prime}$ 's from some countries sell more readily than others.

Up to the end of September 1967, total sales of foreign credits on the BE system mounted to only $\$ 120$ million. This falls considerably short of the targeted $\$ 200$ aid utilization figure as indicated on the 1967 budget. Aid utilization will also depend on an improvement of the BE market which is expected to stem from the regulation introduced at the end of July 1967 whereby $B E$ credit is made available at all state banks, not only at the Central Bank.

Obstacles of a more serious nature which impede effective utilization of aid are the considerable decline in domestic economic activity which has resulted from government stabilization measures, and the government ban on credits for import purposes. The continued pressure on the Government against foreign competition has further tightened the measures against importers in the form of increased prepayment on imports from a previous range of 10 to 25 per cent to the present range of 25 to 50 per cent, causing a further strain on import financing. Accordingly, Indonesian importers were not able to place orders for goods on the credit BE list which they know very well they 
could sell. Of course, if exporters in donor countries could grant credits to importers, the situation would be considerably better. A few American companies have extended such credits during the past months, with favorable results. 22 The present government policy, however, is not conducive to an expansion of such credits. At present, only two types of private import credit are allowed:

1. Short term, not exceeding 180 days;

2. Long term, involving a moratorium of 5 years. The latter type of credit cannot be used for general commodities. These regulations preclude what manufacturers in donor countries might consider normal, workable credit terms of 18 months to 3 years. ${ }^{23}$

Thus, government stabilization policies may, through its restrictive effect on purchasing power and imports, prevent the full utilization of the $\$ 200$ million credit obtained, causing danger to the revenue side of the budget and to the flow of goods into domestic markets. Too much compliance with complaints from inefficient domestic producers who are unable to compete with importers may further aggravate the situation through measures working against a normal course of imports, causing hardship to the masses through a general shortage of goods.

\section{Credit Policies}

Credit policies constitute the third important group of measures taken by the Government within the framework of its stabilization program. It is also the policy which provokes most reactions, quite often unfavorable and in many cases unwarranted, from the private as well as the public enterprise sector as they affect both sectors directly. The policy pursued since 3 October 1966 has been labelled a "tight" money policy, although no ceiling is placed on the total outstanding credit of the banking system.

What has happened is that a return is made to normal banking practices and banking policies from a period of chaos and absence of policy during the previous regime--absence of policy in the sense that a wide discrepancy existed between regulations and actual practice, between what was intended and what happened. In 1965, the banking structure underwent extensive reorganization and the five state commercial banks were integrated into one bank on the same lines as that in the Soviet Union or China.

22. U.S. Embassy, Djakarta, Quarterly Economic Summary, lst quarter 1967, p. 7 .

23. Ibid. 
In February and March 1965, a new credit policy was introduced whereby credits extended by banks were to be based on anticipated results rather than on collateral. Banks were also instructed to allocate 60 per cent of new credit to state and cooperative enterprises and 40 per cent to the private sector. These policy changes led to an upsurge in credit and credit increased by 302 per cent during the year, over twice the increase in 1964 .

Restrictive policies were attempted in January 1966 and in May 1966, but the inflationary forces during the period, coupled with the low interest rates charged by the state banks, caused credits to increase further and, by July, credits extended exceeded the ceiling for the full year.

Effective from I July 1966 , the discount rate was raised and, including commissions to be paid, the cost of credit to the private sector fell to between the range of 26 and 53 per cent per annum. Allowing for a price rise of over 600 per cent in 1966, those fortunate enough to receive credits were therefore paying negative rates of interest and this in turn led to unwanted manipulations in which credits were granted according to the "below the counter" discount the customer was willing to accept. As a result, industries obtained credits far beyond their absorptive capacity and many industries which were operating at 30 per cent of capacity in 1965 obtained credits as if they had been operating at full capacity. In addition, state enterprises could obtain "command credits" for which their credit worthiness was never questioned.

In such a situation, the most important element is the reorganization of the banking system itself and the return to the banking system of its powers to regulate credit and to control its utlization. These reorganization measures were effected prior to 3 October 1966. On that date, the Presidium established new credit policy guidelines. 24 The most important measure has been the drastic increase in interest charges from those effective at that time ranging between 26 per cent and 53 per cent per annum (including commission charges) to a range of between 6 per cent to 9 per cent per month (or between 72 per cent and 108 per cent per annum), still below the then prevailing interest rates in the unorganized market which reportedly varied between 20 and 28 per cent per month towards the end of 1966.25

Under the new directives, short and medium term credits were to be granted to enterprises only for amounts required for the financing of their most urgent current expenditures. Shortterm credits were interpreted to be those which were repayable

24. Presidium Kabinet Ampera, Instruksi, No. 15.

25. Business News, 16 and 19 December 1966. 
within one year, except credits for seasonal crops, while mediumterm credits were meant to be those repayable between one and three years. Longer-terms credits in excess of specified limits laid down by the Central Bank were expressly forbidden. This stipulation mainly affected state enterprises which had in the past borrowed to finance taxes. Furthermore, credits for the financing of imports were strictly forbidden. Credits could only be granted to the following sectors (interest rates in parentheses):

1. Food production ( 6 per cent/month);

2. Export trade, production of export goods, textiles and other goods and transportation purposes ( 7 1/2 per cent/month);

3. Distribution of nine basic consumer goods and other sectors ( 9 per cent/month).

In addition, banks were instructed to ensure that 90 per cent of the new credits should go into activities under 1 and 2 above (production of essential goods, exports and transportation). In granting credits, banks were instructed not to discriminate between state and private enterprises while so-called "command" credits (see above) to state enterprises were strictly forbidden. Regarding export credits, banks were asked to confirm the fact that the exporter was in actual possession of the goods to be exported and had already concluded export exchange contracts. All prefinancing of exports was forbidden while the permissible amount of credit for exports was limited to a maximum of 40 per cent of the value of the export exchange contract. As exporters were previously obtaining up to 100 per cent of their working capital through credits, the new measure was intended to force them to bring back their foreign exchange holdings from "overprice" through the DP market. As such holdings could now be legalized and the exchange rate obtained was determined on the free market, capital inflow originating from DP exchange amounted to $\$ 41$ million in 1966 and to $\$ 10$ million in the first quarter of 1967.26

Under the new regulations, overdue credits bear a penalty rate of 50 per cent above the normal rates while overdrafts carry a penalty of 1 per cent per day. Overdrafts are interpreted as drawings above the ceiling granted; they were often used in the past to finance speculative trade. 27 The Central Bank has been strictly implementing the above measures although the new regulations concerning overdue loans were not implemented

26. See Table 6 above.

27. Drs. Radius Prawiro, Governor of the Central Bank, in an address to the Cabinet Presidium on 6 February 1967. 
until I November for private banks and I December 1966 for foreign exchange banks.

Table 8 shows the effects of the new credit measures on the volume and direction of credits. The effect of the slowdown in credit expansion after the 3 October measures on monetary expansion was shown earlier. In the first quarter of 1967, however, credit became very tight and there appeared a widespread feeling of uneasiness on the part of both state and private enterprise who were most hurt by the new measures. As stated earlier, lack of control and easy terms in the past have misdirected large amounts of credits and the breakdown by end use in the past did not reflect the actual end use of credits. The crackdown on easy credits to state enterprises is reflected on the table as the share of credits going to the government sector has decreased persistently and in August, 1967 credits to the private sector exceeded that to the government sector.

Realizing that production and exports were badly hurt by the too stringent measures taken, the Government gradually eased the tight money measures and credits in the second quarter of the year jumped again by 62.7 per cent with increasing shares going to the production and export sectors. Interest rates were also lowered correspondingly and the latest revisions were effected on 1 July 1967.28

In accordance with these latest revisions, bank rates were lowered to between 3 and 5 per cent per month--three per cent for producers and distributors of nine essential commodities, agriculture, exports and the production of export commodities, transportation and certain other essential industries; four per cent/month for domestic trade and services, while other activities are to be changed 5 per cent. Furthermore, in order to facilitate exports, the maximum credits based on concluded contracts was raised to 75 per cent of the value of the export stocks, while bona fide exporters who have continuously been in the export business for at least the last two years may draw credits not based on exchange contracts. These credits may therefore be used for purchasing. Several exceptions to the above provisions were made. For fertilizers and pesticides, interest rates charged to farmers will be only 1 per cent per month, while public utility companies may obtain working capital credits for rehabilitation at $11 / 4$ per cent a month.

The new rates approximate those prevailing just before the 3 October 1966 measures were introduced. They have, however, been introduced in a climate quite different from that prevailing at that time. For one thing the rate of inflation has considerably slowed down. Also, control has become much tighter with the re-organization of the banking system and the proportion

28. Business News, 19 June 1967. 
Table 8. Total Outstanding Credit According to Sector and Purpose

\begin{tabular}{|c|c|c|c|c|c|c|c|c|c|}
\hline \multirow{2}{*}{\multicolumn{2}{|c|}{ Period }} & \multirow{2}{*}{$\begin{array}{c}\text { Total } \\
\text { Credit } \\
\text { Outstanding }\end{array}$} & \multirow{2}{*}{$\begin{array}{l}\text { Rate of } \\
\text { Increase } \\
\text { in Out- } \\
\text { standing } \\
\text { Credits }\end{array}$} & \multicolumn{2}{|c|}{$\begin{array}{c}\text { Distribution } \\
\text { According to } \\
\text { Sector } \\
\end{array}$} & \multicolumn{4}{|c|}{$\begin{array}{c}\text { Distribution According to } \\
\text { Utilization }\end{array}$} \\
\hline & & & & $\begin{array}{l}\text { Govern- } \\
\text { ment }\end{array}$ & Private & $\begin{array}{l}\text { Pro- } \\
\text { duction }\end{array}$ & Export & $\begin{array}{l}\text { Miscel- } \\
\text { laneous }\end{array}$ & $\begin{array}{l}\text { Special } \\
\text { Projects }\end{array}$ \\
\hline & & $\begin{array}{l}\text { Millions of } \\
\text { Rupiahs }\end{array}$ & Per cent & Per & cent & Per & ent & Per & cent \\
\hline \multicolumn{10}{|c|}{ End of period: } \\
\hline \multirow[t]{4}{*}{$1966:$} & First quarter & $2,042,9$ & -- & 68.2 & 31.8 & 56.3 & 17.5 & 9.4 & 16.8 \\
\hline & Second quarter & $3,250.6$ & 59.0 & 60.4 & 39.6 & 54.9 & 16.1 & 16.6 & 12.4 \\
\hline & Third quarter & $4,599.8$ & 41.5 & 57.5 & 42.5 & 57.3 & 13.8 & 19.6 & 9.3 \\
\hline & Fourth quarter & $6,342.2$ & 37.8 & 59.8 & 40.2 & 59.8 & 14.8 & 18.0 & 7.4 \\
\hline \multirow[t]{4}{*}{ 1967: } & First quarter & $7,638.9$ & 20.4 & 54.5 & 45.5 & 54.9 & 21.4 & 16.5 & 7.2 \\
\hline & Second quarter & $12,429.8$ & 62.7 & 53.0 & 47.0 & 57.1 & 20.6 & 16.5 & 5.7 \\
\hline & July & $14,577.0$ & 17.0 & 50.1 & 49.9 & 56.5 & 21.7 & 16.8 & 5.0 \\
\hline & August ${ }^{a}$ & $17,535.7$ & 20.3 & 48.0 & 52.0 & 55.3 & 23.5 & 16.7 & 4.5 \\
\hline
\end{tabular}

a. Preliminary.

Source: Government of Indonesia, Sub Dewan Moneter, Pengumuman Mengenai Beberapa Statistik Terpenting, 30 May and 30 September 1967. 
of credits going to the production and export sector shown for 1967 are more meaningful than those for 1966 and earlier.

\section{Decontrol of Prices}

The fourth and last series of important measures taken within the framework of the stabilization program have been the attempts to eliminate price distortions resulting from inflation and from a variety of controls in the past. While the main directive issued on 3 october 1966 contained instructions issued by the Presidium pertaining to prices charged by, and to government subsidies to the state enterprises, 29 the politically sensitive drastic increases in rates charged by public utilities and transportation companies did not take place until 10 February 1967. As stated earlier, a similar attempt by the previous Government to raise tariffs in consequence of its ill prepared balanced budget policy for 1966 precipitated major political disturbances which culminated in the downfall of that Government.

The decontrol of prices and the accompanying cessation of subsidies to state enterprises should bring about a substantial decrease in budget expenditures, while the increase in the price of gasoline and of other commodities will provide a significant contribution to revenue through increasing state enterprises profits. It should be noted that, by January 1967, the quarterly rate of subsidies to state enterprises amounted to Rp 5.5 billion, or about 3 times total expenditures on salaries of civil servants. 30 Prior to the February increases in public utility rates, prices charged by other state enterprises and private companies had been raised in conjunction with the new no-subsidy policy of the Government. Thus, in November 1966, prices of basic commodities such as soap, shoes, margarine and sugar were increased by from 14 to 200 per cent. Ocean freight rates were trebled and intennational telecommunication rates were increased tenfold. The rate advances in February 1967 included increases in gasoline and kerosene prices of 700 and 500 per cent respectively; electricity and water rates by 1,100 per cent; postal and domestic telegraph charges, by 1,600 per cent; railway passenger fares, 400 per cent; and Djakarta bus fares, 200 per cent.

In order to soften the impact of these price increases, the Government continued to watch the movement of prices of nine

29. Presidium Kabinet Ampera, Instruksi No. 14, 3 October 1966.

30. Presidium Minister for Economic and Financial Affairs, Sultan Hamengku Buwono IX, before the session of parliament reviewing the drastic rise in public utilities rates on 16 February 1967. 
basic commodities (rice, sugar, salt, kerosene, textiles, coarse batik, coconut oil, salted fish and soap), and subsidies may be granted if necessary to the provision of such essential materials as rice, newsprint, medicine, fertilizers, textbooks and textiles. Actually, a subsidy was given to the importation of cheap textiles at $\mathrm{Rp} 45$ per dollar in anticipation of the Lebaran festivities at the beginning of 1967. The above drastic price rises may appear excessive for a person not familiar with price relationships in Indonesia. They are, however, necessary in view of the failure of the Government to make upward adjustments as inflation continued over several years. One of the justifications for this failure presented by the previous Government was that the Government should act as a price stabilizer and should not follow the pace of inflation. To a certain extent, this can be justified. But, when the price index had risen to 267,276 at the end of 1965, on the basis of 1957-1958 as 100, and most tariffs and rates charged by government companies remained unchanged since 1957 or earlier, an incredible state of price distortions ensued with all evil consequences such as corruption, deterioration of equipment, poor service, etc. resulting therefrom. A case in point is the price of gasoline. At the end of 1965 , gasoline was old Rp 4 per litre. It had remained at that level for years, ignoring price inflation. At the then prevailing black market rate of 50,000 old rupiah to the dollar, it means 0.008 U.S. cents per litre. At that time, the Government attempted to raise the price of gasoline by 250 times to 1,000 old rupiahs or to 1 new rupiah. The political unrest which followed caused Government to reduce the price again to 50 cents (new currency). In February 1967, the price was raised by 700 per cent to 4 new rupiahs. Thus, since December 1965, the price was increased one thousand times. Yet, at the BE rate of 100 rupiahs per dollar, the gasoline price is still only 4 U.S. cents per litre.

Although it would be difficult to specify the details of an operationally meaningful system of interdependent prices, there is little doubt that cases of extreme distortion can be identified. When price control carries price distortions to the extreme, as the Indonesian example indicates, public utility and other enterprises subject to such controls will be unable to cover overheads, let alone generate surpluses for rehabilitation of obsolete equipment. In 1965, even current expenditures could not be covered by receipts. As a result, all such enterprises had to resort to massive subsidies. If such subsidies had been covered by taxes on the rich, we could state that a redistribution to the poor from the rich was taking place, which would have been beneficial from the standpoint of social welfare. This, however, was not the case under the particular conditions of hyperinflation which existed in Indonesia. Subsidies under such circumstances only increased the budget deficit which accelerated the pace of inflation causing additional hardship to workers and other fixed income groups. Extremely low public utility rates meant no relief for the poor as such low tariffs 
provided the officials with an excuse to lower services to below minimum standards. Indeed it benefited the rich as they could, by adding "under the counter" payments, preempt whatever services were left or claim better services. This applied among others to transportation services, hospital services and to schools. Thus, under the circumstances of hyperinflation, what appeared to be a social welfare approach of holding rates and prices down to a minimum in fact benefited and subsidized the more well-to-do classes of the people.

It remains true nevertheless that the initial impact of such drastic price increases in transportation charges and public utilities will be felt more by the poor than by the rich. This situation can be alleviated by providing for progressive rates as have been introduced by the State electric companies. Progressive rates in this important public utility sector will lessen the burden of the lower classes. The same is true for transportation charges and the State Railway Company provides considerable reduction in the fares to school children and armed forces. Ultimately, price decontrol will benefit all users as services provided by those public enterprises may be expected to improve while they are able, through increasing revenues, to replace equipment from surpluses.

Rehabilitation of the Production Apparatus

While the four groups of policy measures discussed at length above were mainly directed towards the stabilization of the economy, they will also have direct or indirect impacts on the rehabilitation of production and therefore on economic development. Some of these effects will be favorable. Thus, the measures taken in the field of exports in line with the stabilization program will at the same time be in conformity with the policy to rehabilitate export production. This is because the added incentive given to exporters in the form of larger percentages of foreign exchange immediately increased local prices of export products, giving further stimulus to producers of these goods.

On the other hand, credit policies, import liberalization and the balanced budget policy have all had unfavorable repercussions on local industry. Import liberalization allowed foreign commodities to undersell the inefficiently manufactured local products. For instance, while ample supplies of PL 480 cotton began to arrive in January 1967, and the spinning mills were quite active, weaving mills operated well below capacity during the first quarter as costs were too high to compete with imported textiles. 31 Other industries, such as the plastics

31. U.S. Embassy, Djakarta, Quarterly Economic Summary, first quarter 1967 , p. 11 . 
and match factories in Djakarta, called for a return to strict import control and the complete prohibition of imports of matchboxes and plastic goods. 32 The tight implementation of a balanced budget affected industries which were dependent on large government contracts, especially from the huge construction projects under the previous regime. Tight credits caused further hardship to local industry. Demands to relax present government policies were therefore voiced especially from the industrial sector, which, however, is still very small in Indonesia and has contributed only an estimated 11 to 13 per cent of national income in recent years. 33

The Government is apparently placed in a dilemma. On the one hand, it is committed to continue its harsh stabilization measures and on the other, it is hard pressed to relax these measures in order to provide relief and protection to domestic industry. At present the Government has apparently decided to continue its efforts to ensure stabilization while at the same time relaxing certain restrictive measures and, for example, lowering interest rates. Continuation of the strict policies is necessary. In the first instance, stability depends on the success of the balanced budget policy which in turn rests heavily on the current utilization of foreign aid and on the fulfillment of export targets. In respect of credits, achievement of stability requires that credit expansion be used for productive purposes. Most importantly, the psychological forces by which inflation is fed cannot easily be eliminated, even if the monetary sources of the inflation have been brought under control. While it is difficult to judge the importance of such forces, a return to expansionary policies now may easily bring back the inflationary spiral with all its consequences.

In addition, too much protection to industry will not be beneficial in the long run. Domestic industry, especially state enterprises, received unusual protection in the past, one of the main causes of their inefficiency in operations. Industry during the last years of hyperinflation had already been operating only at between 15 and 30 per cent of capacity, and the present outcry against the harmful effects of government stabilization policies needs further scrutiny. Unfortunately, statistics on industrial production are lacking and no definite conclusions can be drawn on the effects of government measures on industry.

As stated earlier, the highest legislative body has decided that stabilization and rehabilitation should take precedence over

32. Interview given on a press tour through Djakarta's depressed industries organized by the Bamunas Gaja Baru (Indonesian Chamber of Commerce), Djakarta, 31 May 1967.

33. Pendapatan Nasional Indonesia, 1958-1962 (Djakarta: Biro Pusat Statistik, 1966). 
other matters. In that program, checking inflation should receive first priority, to be followed by the four points in the rehabilitation program: food production and supply, infrastructure, increasing exports and supply of clothing. ${ }^{34}$

With regard to economic development, the cabinet has issued instructions to BAPPENAS, the State Planning Agency, to draw up a five-year economic rehabilitation and development plan which should start in January 1969, to follow the present stabilization and rehabilitation program. ${ }^{35}$ The following sectors are to be given priority in the plan: agriculture, smallscale industry, mining, infrastructure and regional redistribution of population. In addition, education and cultural development are also to be given priority.

The success of the development plan, and of the rehabilitation program, depends not only on the availability of funds but also, and perhaps more importantly, on such human factors as skilis, management and organization of the production apparatus. Steps taken by the present Government to remove obstacles in these areas are partly related to the four sets of measures described earlier, as the following discussion will show.

If enterprises in the modern sector are classified according to ownership, the following three sectors can be identified in Indonesia: (I) Foreign enterprises: large-scale operations in mining, the manufacture of consumer goods and plantation agriculture. (2) "Foreign domestic" enterprises: these are medium- and small-scale enterprises, mostly in the hands of foreign Chinese. (3) State enterprises: include large ex-Dutch trading and manufacturing firms taken over in 1957, plantations, newly established basic industries such as the fertilizer industry in Palembang and many smaller industries, including shops and bakeries taken over from the Dutch in 1957.

Substantial changes have been made in policies towards all three groups under the present regime. Policies towards the first two sectors underwent a complete reversal. During the previous regime, opposition to foreign enterprises became increasingly more apparent and the takeover and nationalization of such companies were gradually carried out, mainly as a consequence of the West Irian and Malaysia conflicts. On the other hand, the second sector which was mainly in the hands of citizens of the People's Republic of China, was rather favorably treated, the reason given being that such foreign "domestic" capital was progressive as capital and profits were not transferred, and

34. See first section above.

35. Instruksi Presidium Kabinet Ampera No. 15/EK/IN/3/1967, issued on 14 March 1967, followed by a more detailed instruction of the President, (Instruksi Presiden No. 03/1967), issued on 4 June 1967. 
was therefore to be considered a "tool of the revolution." It is true that such capital was not transferred officially but it is believed that illegal capital flight from this sector contributed in no small measure to the rapid depreciation of the rupiah.

The present Government welcomes foreign private investment, as indicated by the recent foreign investment bill and by the gradual return to the owners of such companies as the Goodyear Tyre Factory (United States), Unilever Soap and Margarine Factory (British) and the BATA Shoe Factory (Canadian), which were taken over (expropriated) during various stages of the confrontation against Malaysia. Negotiations are also under way for the return of British and Malaysian plantations, but this is proving to be more difficult to implement as the managements in charge of the enterprises taken over appear reluctant to relinquish their positions. On the other hand, foreign Chineseowned capital has increasingly come under fire and a solution is being worked out by a special committee.

The new foreign investment law was approved by the Parliament in December 1966 and signed by the President on 10 January 1967. The law permits direct foreign investment in all areas except defense industries. In vital industries, such as transportation, energy and communications, only joint ventures are permitted. In addition to the privileges granted to foreign investors, such as tax exemption up to five years from the start of production, exemption from import duties on capital equipment, etc., compensation in the event of nationalization, and repatriation of profits, foreign investors are obliged to provide genuine opportunity for local capital participation following a specified period. The foreign owners receive full authority to appoint their managers, provided that foreign personnel are appointed only to positions which cannot be filled by Indonesian nationals and that facilities for the training of Indonesians are established.

The last two provisions may somewhat diminish the attractiveness of investment opportunities for foreign capital and a large-scale inflow of such capital will probably not be the direct result of the new law. For one thing, other developing countries offer similar and in some cases more attractive terms, and some have a better record of political and economic stability. From the Indonesian standpoint, large-scale inflow of foreign capital is probably neither expected nor wanted, and joint ventures are preferred.

Nevertheless, the prolonged insulation of Indonesia from foreign private capital may make it relatively more attractive to invest capital there than in similarly situated countries, while the abundance of unexploited natural resources provides 
another incentive. ${ }^{36}$ on the basis of preliminary enquiries by foreign firms, the Government expects an annual inflow of $\$ 100$ million in direct foreign investments. 37

Policy with regard to state enterprises has also undergone a fundamental change. State enterprises, as stated earlier, consist of large trading and manufacturing enterprises, banks, insurance firms and plantations taken over from Dutch interests in 1957 and from British and other interests during the course of confrontation with Malaysia. It also includes new companies established by the Government in large-scale industry and in public utilities and transportation. The last one was established in June 1967 to manage the nearly completed Djatiluhur multipurpose dam.

Except for public utilities and transportation, state enterprises were expected to earn surpluses. Their contribution to the state is to consist of a 50 per cent share in their profits and a donation of 55 per cent profits after tax to the development fund. In return, they receive special treatment from the Government in the form of easy credit, foreign exchange allocations and monopolies in the trade and distribution of certain essential commodities. They are intended to become training institutions for the development of a national entrepreneurial class while their status as state enterprises is expected to be in conformity with the principles of Indonesian socialism.

Since 1960 , state enterprises have been grouped according to their type of activity and been formed into separate industrial organizations or perusahaan negara, each directed by a General Management Board (Badan Pimpinan Umum, BPU). These management boards were set up as co-ordinating bodies, but in reality they only formed part of the process of bureaucratization. The present Government, in its attempt to reduce and streamline the bureaucracy has instructed that BPU's which serve no useful purpose be abolished.

As a source of public revenue the state enterprises were not very successful. Revenues from such enterprises as a percentage of total government income dwindled from 1.9 per cent in 1960 to an estimated 0.4 per cent in 1966. Moreover, many state enterprises obtained credits for payment of taxes while others were granted substantial subsidies. The present policy of non-favoritism is in conformity with one of the most important

36. The first company to sign an agreement under the new law was an American company, Freeport Sulphur, which concluded an agreement with the Government for the exploration and subsequent exploitation, if warranted, of copper deposits in West Irian. U.S. Embassy, Quarterly Economic Report, Ist quarter $1967, \mathrm{p} .8$.

37. Sultan Hamengku Buwono IX in a report to the Parliament on 10 July 1967. 
functions accorded to these enterprises, namely, to provide training for the establishment of a new entrepreneurial class which should eventually replace the foreign sector. The equal facilities provided to these enterprises and to private firms should provide a stimulus to managements of state enterprises to work according to economic principles and to show more initiative. Overprotection in. the past has created not entrepreneurs, but bureaucrats who know how to spend but not how to work efficiently. This is, of course, a harsh generalization which does not apply to all enterprises. Several state enterprises have worked very well, performing their functions according to expectations and some may have even exceeded expectations.

\section{Summary and Conclusions}

Thus far the most important achievement of the Government's stabilization and rehabilitation program has been the initial reduction in the rate of inflation. Undoubtedly, this achievement has been mainly due to the stringent balanced budget and tight money policies which have been applied vigorously since october, 1966. As a result, monetary expansion has slowed down considerably. Another factor, of perhaps equal importance is psychological; its effects can be seen indirectly in the statistics on money supply and inflation. During the last quarter of 1966 and the first half of 1967, the rate of increase in the money supply has exceeded that of the price level. This appears to be a reversal of what had occurred since 1960. It suggests at least a tentative restoration of confidence in the currency and in the Government. Although this qualitative element cannot be measured directly it is undoubtedly influenced by the earnestness with which the Government is pursuing its stated purpose to ahieve stabilization. The brief experience with stabilization policies suggests that both quantitative monetary action and propaganda to publicize the Government's intentions are required if confidence is to be restored.

The psychological element is also evident in the stabilization of the exchange rate. Stringent exchange controls aimed to stop the outflow of capital had in the past caused exactly the opposite to occur. Fear of inconvertibility of the rupiah led to a considerable illegal capital outflow necessitating further tightening of controls which in turn induced more people to transfer their wealth abroad, depreciating the currency even further. The relaxation of controls, coupled with the increasing share of foreign exchange earnings retained by exporters and the legalization of foreign exchange holdings, has led to a restoration of confidence and thus contributed in no small measure to the stabilization of the rupiah exchange rate.

An assessment of qualitative elements which have contributed to the reduction in the rate of inflation should not overshadow 
the importance of quantitative stabilization measures. Moreover, psychological factors can work both ways and a reversal of policies at this stage may, through its psychological impact, bring back inflation in its full force. Nevertheless, some relaxation of the tight money policy may not be entirely precluded. In the past, it was not only the increase in the volume of credit which was conducive to inflation, but also the actual use of credit since lack of control often permitted the diversion of credits to unproductive uses. Thus an increase in the volume of credit, coupled with more stringent controls to ensure its productive use, should help alleviate the stagnation in both exports and industrial production.

The repercussions of the stabilization policies on economic activities were not unexpected. That the drastic reduction of the inflation rate produced unfavorable effects on certain activities came as no surprise. Industries and trade geared to inflationary demand are particularly sensitive to stabilization. The repercussions, however, were not confined to these sectors alone and virtually all domestic industries complained about competition from imports, tight money and a lack of effective demand.

Extreme care should be exercised in the interpretation of such complaints. In the period of strict import controls necessitated by stagnant exports in the past, domestic industry had enjoyed extraordinary protection. Protection came also in the form of easy credits at far below market rates of interest, and of import allocations for raw materials at low rates of exchange. As a result, credits and import allocations were diverted to other uses, while industry operated at 15 to 30 per cent of capacity. All these factors have recently came to light as decontrol measures were introduced and subsidies to state enterprises ceased. In fact, the present policy whereby state enterprises are to compete on an equal basis with private enterprises may in the long run prove to be more in conformity with the purposes for which they were established, namely to provide an important source of revenues for the Government and to fulfil the objectives of Indonesian socialism. They may also become, through competition, a training ground for a truly national entrepreneurial class.

In its policy of balancing the budget, the Government should consider the size of the budget in relation to national income. In the past inflation drastically reduced the Government claim on real resources. This is reflected in the low level of real income enjoyed by civil servants from their government jobs, making it necessary for them to search for supplementary sources. As stabilization has proceeded such sources, frequently in the form of petty speculative trading, will be eliminated while curtailment of the government budget has liquidated income sources from makework research and other projects. A substantial increase in government salaries should be preceded by a rationalization 
process and by an increase in government revenue. The exceptionally small proportion of taxes in relation to national income suggests the existence of potentially large sources of government revenues. These can again only be tapped after a reorganization of the tax system and a cessation of illegal "taxes" which the majority of people are paying at present.

The $\$ 200$ million balance of payments loan obtained for 1967 will contribute to the stabilization of the exchange and to the flow of goods. However, its utilization thus far has fallen short of expectations. Measures against importers in the form of cessation of credits and increased prepayments have, combined with general lack of effective demand and deteriorating distributive system, made it difficult for importers to increase import contracts, especially since foreign exchange from foreign credits can only be used for a limited number of goods obtainable only from the creditor country. This may seriously hamper the flow of goods to the domestic market and will have adverse repercussions on the government budget. The Government may therefore be faced with a problem which is novel in Indonesia: the necessity to encourage imports. One way to do so is, of course, by lowering the $\mathrm{BE}$ rate charged by the Government for foreign exchange obtained from external credits. This may have a beneficial effect on other BE rates, including that on exchange originating from private export earnings. Moreover, domestic producers will not be harmed by $B E$ rates because credit $\mathrm{BE}^{\prime}$ 's are to be used for spare parts and raw material imports.

Increased incentives to exporters seem to have partly offset tight credit and high interest charges, judging from the export performance in the first half of 1967. If such performance continues, particularly after the new incentives introduced on $28 \mathrm{July} 1967$ the export target of $\$ 475$ million (excluding oil) may well be achieved by the end of the year. It should nevertheless be recalled that exports have been quite stagnant for more than a decade. Rapid economic growth cannot be achieved without a more-than-normal increase in exports to compensate for past stagnation. Obstacles are many--administrative, physical and financial--all of which have contributed to smuggling and the decline of exports. The Government may remove the incentive to smuggle by giving adequate returns to the exporter. Administrative obstacles in the form of widespread corruption in the ports, which results in excessive port costs, must be removed, physical obstacles will gradually be reduced with the rehabilitation of infrastructure. Unfortunately this rehabilitation is proceeding slowly because of curtailment of the development budget. Although the development budget is much smaller proportionally than in previous years, it puts emphasis on real development projects such as dredging, flood control, irrigation and highways, while unrealistic development expenditures such as imaginary research projects have been abolished. 
It should be clear from the foregoing discussion that the improvements in the Indonesian economy achieved thus far will provide the basis for further improvements and help to provide the preconditions for rapid economic growth in the near future. Nevertheless, serious problems remain to be overcome. Those which have arisen from the painful adjustments necessary to combat inflation and general economic deterioration should not prevent the Government from carrying out its intentions. Meanwhile, the Government must build flexibility into its program, based on the experience gained in the course of implementation. Among the measures to combat inflation, psychological elements are perhaps as important as monetary factors. In the long view, it is rapid economic development which is desired. Stabilization and rehabilitation are only preliminary steps towards achieving this end. 